\title{
UNIA EUROPEJSKA JAKO OBSERWATOR PRZY ZGROMADZENIU OGÓLNYM ORGANIZACJI NARODÓW ZJEDNOCZONYCH
}

\section{WSTEP}

Zgromadzenie Ogólne Organizacji Narodów Zjednoczonych (ZO ONZ) 3 maja 2011 r. uchwaliło rezolucję 65/276 w sprawie udziału Unii Europejskiej (UE) w pracach ONZ ${ }^{1}$, co zakończyło proces powiększania się roli, jaką UE odgrywa w ZO w rezultacie wejścia w życie Traktatu z Lizbony (TL) ${ }^{2}$. Wydarzenie to zostało bardzo pozytywnie ocenione przez Wysoką Przedstawiciel UE ds. Zagranicznych i Polityki Bezpieczeństwa, która stwierdziła, że uchwalenie powyższej rezolucji ,umożliwi przedstawicielom UE przedstawianie i promowanie stanowisk UE w ONZ, uzgodnionych przez jej państwa członkowskie" ${ }^{3}$. Zauważyć bowiem wypada, że TL w znaczący sposób powiększył kompetencje UE w zakresie występowania w stosunkach z innymi państwami lub organizacjami międzynarodowymi ${ }^{4}$. Na podstawie Traktatu z Lizbony UE m.in. uzyskała podmiotowość prawną, rotacyjne przewodnictwo zostało zastąpione stałym Przewodniczącym Rady Europejskiej oraz Wysokim Przedstawicielem ds. Zagranicznych i Polityki Bezpieczeństwa, który przewodniczy Radzie ds. Zagranicznych i wspomagany jest przez Europejską Służbę Działań Zewnętrznych (ESDZ). Zadanie reprezentowania UE na zewnątrz (poza wspólną polityka zagraniczną i bezpieczeństwa oraz innymi wypadkami przewidzianymi w traktatach) powierzono ponadto Komisji Europejskiej.

Wskutek zmian wprowadzonych przez TL zmieniło się również stanowisko UE w odniesieniu do jej pozycji zajmowanej w organach i organizacjach systemu Narodów Zjednoczonych (NZ) ${ }^{5}$. W wypadku Rady Bezpieczeństwa (RB) ONZ, art. 34 ust. 2 Traktatu o Unii Europejskiej (TUE) stanowi, że państwa członkowskie UE, które w niej zasiadaja, moga wnieść o zaproszenie Wysokiej

\footnotetext{
${ }^{1}$ A/RES/65/276. Participation of the European Union in the work of the United Nations.

${ }^{2} \mathrm{Na}$ ten temat zob. M. Menkes, Rewizja statusu obserwatora UE przy ONZ (między regionalizmem a uniwersalizmem), „Państwo i Prawo” 2012, z. 11, s. 85 i n.

${ }^{3}$ Statement by the High Representative Catherine Ashton on the adoption of the UN General Assembly Resolution on the EU's participation in the work of the UN, Brussels, 3 May 2011, A 172/11.

${ }^{4} \mathrm{Na}$ ten temat zob. K. E. Jørgensen, R. A. Wessel, The Position of the European Union in (Other) International Organizations: Confronting Legal and Political Approaches, w: P. Koutrakos (red.), European Foreign Policy: Legal and Political Perspectives, Edward Elgar Publishing 2011, s. 261 i n.; R. A. Wessel, The Legal Framework for the Participation of the European Union in International Institutions, ,Journal of European Integration” 33, 2011, s. 621 i n.

${ }^{5}$ M. Emmerson, J. Wouters, The EU's Diplomatic Debacle at the UN. What Else and What Next?, „Centre for European Policy Studies”, 1 October 2010, s. 1.
} 
Przedstawiciel do udziału w obradach Rady, jeżeli UE określiła stanowisko w kwestii wpisanej do porządku obrad RB. W praktyce od początku 2010 r. współpraca pomiędzy Unią a Radą zaczęła układać się bardzo poprawnie, ponieważ UE zaczęła być zapraszana do udziału w otwartych debatach RB ONZ. Praktyka ta znalazła swoja podstawę w art. 39 regulaminu wewnętrznego Rady, który pozwala temu organowi zaprosić na jego posiedzenie członków Sekretariatu lub inne osoby, uznawane za kompetentne do przedstawienia informacji lub udzielenia innej pomocy podczas badania kwestii mieszczących się $\mathrm{w}$ ramach jego kompetencji ${ }^{6}$. Na tej podstawie od $2010 \mathrm{r}$. przedstawiciele Unii (w tym Wysoka Przedstawiciel), zaczęli składać na forum Rady tzw. oświadczenia UE ( $E U$ Statements), które zastapiły składane wcześniej tzw. oświadczenia prezydencji ${ }^{7}$.

Wejście w życie Traktatu z Lizbony nie spowodowało jednak większych zmian w odniesieniu do pozycji, jaką Unia zajmowała w Zgromadzeniu Ogólnym ONZ. Jako jedna $\mathrm{z}$ wielu organizacji międzynarodowych posiadających status obserwatora przy tym organie, UE mogła składać swoje oświadczenia poprzez przedstawicieli (państwa sprawującego prezydencję) dopiero po wypowiedziach przedstawicieli wszystkich państw członkowskich $\mathrm{ONZ}^{8}$. Z tego powodu UE podjęła działania w celu zmiany jej statusu przy ZO ONZ, w rezultacie których uchwalono wspomnianą powyżej rezolucje $65 / 276$. W piśmiennictwie polskim określa się obecny „wzmocniony” status UE jako ,,super obserwatora” przy ZO ${ }^{9}$. Zauważyć jednak należy, że sama rezolucja 65/276 w swoim tytule mówi o ,udziale UE w pracach ONZ” (Participation of the European Union in the work of the United Nations), nie wymieniajac ani $\mathrm{ZO}$, ani nie wspominając o obserwowaniu jego prac.

Celem prezentowanego opracowania jest scharakteryzowanie praw, jakie dla Unii Europejskiej wynikaja z postanowień rezolucji 65/276. Osiagnięcie tak zakreślonego celu wymaga jednak w pierwszej kolejności przedstawienia dotychczasowego statusu Unii w Zgromadzeniu Ogólnym ONZ (jako „zwykłego” obserwatora"), a także charakterystyki wysiłków podjętych przez UE bezpośrednio przed uchwaleniem omawianej rezolucji.

\section{RODZAJE STATUSU OBSERWATORA PRZY ORGANIZACJACH MIEDZYNARODOWYCH}

W piśmiennictwie dzieli się obserwatorów przy organizacjach międzynarodowych na kilka rodzajów (typów) ${ }^{10}$. W pierwszej kolejności wyróżnić

\footnotetext{
${ }^{6}$ Provisional Rules of Procedure of the Security Council, New York, 1983, S/96/Rev.7.

${ }^{7}$ Lista i treść tych oświadczeń dostępna na: http://www.europa-eu-un.org/articles/articleslist_ s52_en.htm.

${ }^{8} \mathrm{Na}$ temat wcześniejszego udziału UE w pracach ZO zob. J. Wouters, The European Union as an Actor within the United Nations General Assembly, K.U. Leuven, Faculty of Law, Institute for International Law, ,Working Paper” 2001, nr 2 (May).

${ }^{9}$ R. Tarnogórski, Unia Europejska w ONZ: multilateralizm w praktyce, ,Biuletyn PISM” nr 72 (821), 8 lipca $2011 \mathrm{r}$.

${ }^{10} \mathrm{~N}$. Sybesma-Knol, The Continuing Relevance of the Participation of Observers in the Work of the United Nations, w: K. Wellens (red.), International Law, Theory and Practice - Essays in Honour of Eric Suy, The Hague 1998, s. 374. Niektórzy z autorów zajmujących się omawianym zagadnieniem wyróżniaja
} 
można państwa niebędące członkami danej organizacji ${ }^{11}$, następnie inne organizacje międzynarodowe, po trzecie narodowe ruchy wyzwoleńcze i wreszcie organizacje pozarządowe ${ }^{12}$. W odniesieniu do organizacji międzynarodowych rządowych, wyróżnić z kolei można takie, które należą do systemu Narodów Zjednoczonych (wyspecjalizowane) oraz inne, pozostające poza tym systemem ${ }^{13}$. Organizacje wyspecjalizowane związane są z ONZ na podstawie art. 57 oraz art. 63 Karty NZ, które stanowią, że warunki ich współpracy z ONZ mają być określone w porozumieniach zawieranych przez nie z Rada Gospodarczą i Społeczną (RGS) ${ }^{14}$. Organizacje międzynarodowe nienależące do systemu NZ mogą natomiast brać udział w pracach organów ONZ tylko po wyrażeniu przez nie zgody. Pod koniec 2012 r. liczba organizacji międzynarodowych posiadajacych status obserwatora przy ZO ONZ, a nienależących do Systemu NZ wynosiła - 69 ${ }^{15}$. Jako pierwsza w 1948 r. status obserwatora otrzymała Organizacja Państw Amerykańskich ${ }^{16}$. W następnej kolejności status ten uzyskały m.in. Liga Państw Arabskich ${ }^{17}$ i Organizacja Jedności Afrykańskiej (OJA) ${ }^{18}$.

Karta NZ ani regulamin wewnętrzny ZO ONZ nie określają procedury nabycia statusu obserwatora $\mathrm{w}$ tym organie. W zdecydowanej większości przypadków status ten nabywany jest na podstawie rezolucji $\mathrm{ZO}$, w których zaprasza się daną organizację międzynarodową do wzięcia udziału w jego pracach w charakterze obserwatora i zobowiązuje Sekretarza Generalnego (SG) ONZ do podjęcia wszelkich działań w celu wprowadzenia w życie tej rezolucji ${ }^{19}$. Wyjątkowym pod tym względem jest Międzynarodowy Trybunał Karny, którego status obserwatora wynika z porozumienia zawartego z ONZ ${ }^{20}$.

Procedurę przyznania określonej organizacji międzynarodowej statusu obserwatora w ZO reguluje kilku różnych dokumentów. W pierwszej kolejności wskazać należy na decyzję ZO 49/426 z 9 grudnia 1994 r., w której ZO stwierdziło, że przyznanie statusu obserwatora w ZO powinno być w przyszłości ograniczone do państw i organizacji międzyrządowych, których działalność dotyczy kwestii będących przedmiotem jego zainteresowania. W 1999 r. ZO

także piąta kategorię obserwatorów, którymi według nich są jednostki, zob. H. G. Schermers, N. M. Blokker, International Institutional Law, The Hague 1995, s. 122.

${ }^{11}$ Zob. Seung Hwan Choi, The Status, Rights and Duties of Observers for Non-Member States of the United Nations, ,Korean Journal of Comparative Law” 19, 1991, s. 135 i n.; G. Grabowska, Obserwatorzy państw w powszechnych organizacjach międzynarodowych, Warszawa 1978.

${ }^{12}$ N. Sybesma-Knol, op. cit., s. 374.

13 E. Suy, The Status of Observers in International Organizations, RdC 1978, t. 2, s. 96.

${ }^{14}$ Dodać należy, że Karta NZ zawiera jeszcze dwa inne postanowienia dotyczące organizacji wyspecjalizowanych. Zgodnie z art. 70 Karty RGS może zawierać porozumienia z organizacjami wyspecjalizowanymi w sprawie udziału ich przedstawicieli w jej obradach. Natomiast art. 91 Karty stanowi, że Rada Powiernicza może korzystać z pomocy organizacji wyspecjalizowanych.

${ }^{15} \mathrm{~W}$ tym 19 organizacji posiadających stałe misje przy ZO, zob. informacje na stronie www.un.org/en/members/intergovorg.shtml.

16 A/RES/253 (III).

$17 \mathrm{~A} / \mathrm{RES} / 477(\mathrm{~V})$.

${ }^{18} \mathrm{~A} / \mathrm{RES} / 2011(\mathrm{XX})$.

19 Zob. np rezolucję A/RES/51/6 dotyczącą Międzynarodowej Organizacji Dna Morskiego.

${ }^{20}$ Relationship Agreement between the United Nations and the International Criminal Court, UNTS, vol. 2283, II-1272. 
zdecydowało natomiast, że wszystkie wnioski składane przez organizacje międzynarodowe w sprawie przyznania statusu obserwatora będą rozstrzygane w trakcie sesji plenarnych, po uprzednim ich rozważeniu przez Szósty Komitet $\mathrm{ZO}$ (ds. prawnych) ${ }^{21}$. Do wniosku powinno być dołączone memorandum wyjaśniające oraz jeśli to możliwe, podstawowe dokumenty dotyczące organizacji lub projekt rezolucji ${ }^{22}$. Jeżeli wniosek zostanie wpisany do programu prac ZO (na zalecenie Komitetu Ogólnego ZO), projekt rezolucji w sprawie statusu obserwatora danej organizacji powinien zostać poparty przez jej państwa członkowskie $^{23}$. W dalszej kolejności państwa członkowskie ONZ głosuja $\mathrm{w}$ sprawie przyjęcia projektu takiej rezolucji.

Decyzja w sprawie przyznania określonej organizacji międzynarodowej statusu obserwatora w ZO należy wyłącznie do państw członkowskich ONZ. Rola SG ONZ w tym procesie polega jedynie na podjęciu niezbędnych kroków mających przypomnieć państwom członkowskim, jakie kryteria i procedury należy zastosować $\mathrm{w}$ tej mierze. Sekretarz Generalny nie może przy tym podejmować żadnych interwencji, których celem byłoby np. „mobilizowanie” działań organizacji wnioskującej o przyznanie jej statusu obserwatora ${ }^{24}$.

Zakres praw przysługujacych organizacjom międzynarodowym posiadajacym status obserwatora przy ZO ONZ nie jest precyzyjnie określony i wynika bardziej z praktyki funkcjonowania ZO niż z wiążących dokumentów. Niemniej jednak ONZ podejmowała już próby niewiążącej „,kodyfikacji” zasad udziału innych organizacji międzynarodowych $\mathrm{w}$ jej pracach ${ }^{25}$. W wypadku niektórych organizacji międzynarodowych ich prawa wynikające z statusu obserwatora były również precyzowane w późniejszych rezolucjach (tzn. uchwalonych już po uzyskaniu statusu obserwatora), co miało miejsce np. wobec OJA ${ }^{26}$.

Generalnie zatem organizacje międzynarodowe posiadajace status obserwatora w ZO ONZ mogą: brać udział w posiedzeniach ZO i jego komitetów oraz grup roboczych, uzyskiwać dostęp do oficjalnych dokumentów ZO, brać udział $\mathrm{w}$ dyskusjach $\mathrm{w}$ kwestiach będących przedmiotem ich zainteresowania, zasiadać w czasie obrad ZO w specjalnie wyznaczonych dla nich miejscach (dotyczy to tylko tych organizacji międzynarodowych, które posiadają stałe przedstawicielstwa przy siedzibie $\mathrm{ONZ})^{27}$. Obserwatorzy nie maja natomiast

${ }^{21}$ Observer status for the International Union for the Conservation of Nature and Natural Resources in the General Assembly, A/RES/54/195, 17 February 2000, § 2.

${ }^{22}$ Procedures for Obtaining Observer Status with the General Assembly of the United Nations, (Facsimile to the Legal Counsel of the South Pacific Regional Environmental Programme), „United Nations Juridical Yearbook" 1998, s. 484.

23 Ibidem.

${ }^{24}$ Observer Status in the General Assembly for the Inter-Parliamentary Union - Procedures for Obtaining Observer Status with the United Nations for Intergovernmental Organizations - Question Whether the Secretary-General May Intervene in the Process (Memorandum to the Assistant Secretary-General for External Relations, „United Nations Juridical Yearbook” 2000, s. 363.

${ }^{25}$ Guidelines for Implementation of General Assembly Resolutions Granting Observer Status on a Regular Basis to Certain Regional Intergovernmental Organizations, the Palestine Liberation Organization and the National Liberation Movements in Africa, Note for the Secretariat, 31 January 1975, „United Nations Juridical Yearbook” 1975, s. 164-167.

${ }^{26} \mathrm{~A} / \mathrm{RES} / 3280$ (XXIX).

${ }^{27}$ P. A. Serrano de Haro, Participation of the European Union in the Work of the United Nations: General Assembly Resolution 65/276, „CLEER Working Papers” 2012/4, s. 12. 
prawa do składania projektów rezolucji lub wniosków proceduralnych, wnoszenia punktów porządku obrad, odpowiedzi, rozpowszechniania własnych dokumentów jako dokumentów ZO, a także prawa do udziału w głosowaniach ${ }^{28}$.

Rezolucje przyznające organizacjom międzynarodowym status obserwatora w ZO nie określają również zakresu przywilejów i immunitetów przysługujących ich misjom przy ONZ. Z praktyki wynika jednak, że ONZ przyznaje misjom organizacji międzynarodowych niektóre prawa przysługujące stałym przedstawicielstwom państw na podstawie Karty NZ oraz Porozumienia pomiędzy ONZ a USA w sprawie siedziby $\mathrm{ONZ}^{29}$. Tak więc misje organizacji międzynarodowych będą mogły korzystać z takich immunitetów, jak: immunitet jurysdykcyjny w odniesieniu do działań podjętych przez członków misji w związku z wykonywaniem ich oficjalnych funkcji przed danym organem ONZ, nietykalność dokumentów dotyczących ich stosunków z ONZ, a także samych pomieszczeń misji, dostęp do siedziby organów ONZ, możliwość uzyskania wiz wjazdowych państwa, na którego terytorium znajduje się siedziba danego organu $\mathrm{ONZ}^{30}$.

\section{PRZYGOTOWANIA DO WZMOCNIENIA STATUSU OBSERWATORA UNII EUROPEJSKIEJ PRZY ZGROMADZENIU OGÓLNYM ONZ}

Idea wzmocnienia statusu obserwatora, który Unia Europejska (dawna Europejska Wspólnota Gospodarcza) miała w Zgromadzeniu Ogólnym ONZ już od 1974 r. ${ }^{31}$, pojawiła się po raz pierwszy w 1994 r. W rezolucji dotyczącej roli UE w ONZ Parlament Europejski zaproponował wtedy, aby w związku z podjęciem wszelkich niezbędnych środków instytucjonalnych dotyczących wspólnej polityki zagranicznej i bezpieczeństwa rozważyć przyznanie UE statusu pełnego członkostwa w $\mathrm{ZO}$ oraz RB ONZ ${ }^{32}$.

Pierwszy projekt rezolucji dotyczącej udziału UE w pracach ONZ został jednak przedstawiony przez państwa członkowskie UE dopiero w sierpniu 2010 r. ${ }^{33}$ Zasadniczym celem, który UE chciała osiągnąć w związku z jego uchwaleniem, było co najmniej utrzymanie dotychczasowej jej pozycji w ZO,

${ }^{28}$ Right to Vote of a Union or Group of Member States. Rights of the European Community in the General Assembly (Letter to the Director, Office of International Standards and Legal Affairs, United Nations Educational, Scientific and Cultural Organization), „United Nations Juridical Yearbook” 1995, s. 438 .

${ }^{29}$ Legal Status of the Permanent Observer Mission of the Organization of the Islamic Conference - Privileges and Immunities of Non-State Entities Invited to Participate as Observers in United Nations Meetings (Letter to the Permanent Representative of a Member State), „United Nations Juridical Yearbook" 1999, s. 408.

${ }^{30}$ Ibidem, s. 409.

${ }^{31}$ A/RES/3208/XXIX. Status of the European Economic Community in the General Assembly, 11 October 1974.

${ }^{32}$ European Parliament: Resolution on the Role of the Union within the UN and Problems of reforming the UN, A-3/0331/93, OJ 1994, C 61, s. 43.

${ }^{33}$ Draft Resolution: Participation of the European Union in the work of the United Nations, A/64/L.67, 31 August 2010. 
mogła się ona bowiem pogorszyć $\mathrm{w}$ związku z wejściem w życie $\mathrm{TL}^{34}$. W preambule projekt rezolucji podkreślał zatem wpływ, jaki wejście $\mathrm{w}$ życie TL wywiera na zasady reprezentacji UE w stosunkach zewnętrznych. Projekt wymieniał również nowo powołane organy i przedstawicieli UE działających $\mathrm{w}$ stosunkach zewnętrznych. Ponadto podkreślano, że w sytuacji, w której regionalna organizacja integracyjna (taka jak UE) rozwija wspólną politykę zewnętrzną i tworzy stałe struktury jej realizacji, ZO ONZ może odnosić korzyści z ich udziału w sytuacji, w której przemawiają one w imieniu UE i jej państw członkowskich. W swojej części operacyjnej projekt rezolucji z sierpnia 2010 r. daje przedstawicielom UE prawo do: wygłaszania przemówień, rozpowszechniania dokumentów, przedstawiania projektów i poprawek, przedstawiania punktów porządku (z wyłączeniem podważania decyzji przewodniczącego obradom). Unia Europejska nie mogła natomiast brać udziału w głosowaniach oraz przedstawiać kandydatów w ZO ONZ.

Projekt rezolucji w sprawie udziału UE w pracach ONZ po wprowadzeniu do niego niewielkich modyfikacji został przedstawiony ZO we wrześniu $2010 \mathrm{r}^{35}$, podczas 64 sesji, niemniej jednak nie spotkał się z poparciem większości państw członkowskich ONZ. Przedstawiciele niektórych z nich (m.in. Lesoto w imieniu Grupy Afrykańskiej, Surinamu w imieniu Karaibskiej Wspólnoty i Wspólnego Rynku [CARICOM], Nauru, Boliwii) podnosili, że projekt ten jest tak ważny, iż wymaga staranniejszego rozpatrzenia, w związku z czym należy odłożyć na pewien czas decyzję o jego przyjęciu. Skutkiem takiej postawy wspomnianych państw (do których przyłączyły się ponadto Chiny, Indie i Rosja) wniosek UE $\mathrm{w}$ sprawie uchwalenia przygotowanego przez nia projektu rezolucji został odroczony przez $\mathrm{ZO}^{36}$. W piśmiennictwie wskazuje się, że o niepowodzeniu UE zdecydowała niechęć mniejszych państw członkowskich ONZ do zmiany międzyrządowego charakteru $\mathrm{ZO}^{37}$. Poza tym państwa członkowskie ONZ należące do innych organizacji regionalnych uznawały, że wzmocnienie statusu UE w ZO zapoczatkuje proces wzmacniania pozycji innych organizacji regionalnych. Oczekiwanie to z kolei wzbudziło zaniepokojenie dużych państw: zaczęły się obawiać możliwości (na razie raczej odległej) pojawienia się w ZO dużych bloków regionalnych, które zmieniłyby dotychczasowy rozkład sił i osłabiły ich pozycję ${ }^{38}$. Ostatnim z powodów odrzucenia projektu rezolucji w sprawie wzmocnienia statusu UE w ZO ONZ stał się tradycyjny podział Północ - Południe. Niektóre państwa Południa uznawały, że UE chce dla siebie nadmiernych przywilejów, które by w nieuzasadniony sposób odróżniały jej status od innych obserwatorów.

\footnotetext{
${ }^{34}$ Przed wejściem w życie TL działania w imieniu UE podejmowane były przez państwo członkowskie sprawujące rotacyjne przewodnictwo, w związku z czym stanowiska UE przedstawiane były w kolejności przysługującej państwom członkowskim ONZ. Skutkiem samodzielnego działania UE na forum ZO miała być natomiast „degradacja” jej znaczenia, ponieważ przedstawiciele obserwatorów występują zawsze po państwach członkowskich, zob. P. A. Serrano de Haro, op. cit., s. 16.

${ }^{35}$ UNGA Official Records, A/64/PV.122, 14 September 2010.

${ }^{36} \mathrm{Za}$ odroczeniem projektu rezolucji głosowało 76 państw, przeciwko - 71 .

${ }^{37}$ G. Grevi, From Lisbon to New York: The EU at the UN General Assembly, FRIDE Policy Brief, No. 81, June 2011, s. 2.

38 Ibidem.
} 
Niepowodzenie UE związane z odrzuceniem projektu rezolucji pochodzącego z sierpnia 2010 r. nie zakończyło wysiłków związanych z podniesieniem jej statusu w ZO ONZ. Wyniki głosowania w sprawie uchwalenia projektu rezolucji omówione zostały przez Radę ds. Zagranicznych na spotkaniu 16 września 2010 r. Ponadto Wysoka Przedstawiciel powołała specjalną ,grupę zadaniowa ds. rezolucji”, której powierzono zadania związane z przygotowaniem, konsolidowaniem i wspieraniem prac delegatury UE przy ONZ, przedstawicieli UE w państwach trzecich oraz sekretariatów Komisji i Rady w celu stworzenia warunków gwarantujących sukces w kampanii zmierzającej do zapewnienia UE efektywnego udziału w pracach $\mathrm{ZO} \mathrm{ONZ}^{39}$. Dodać również należy, że w lutym 2011 r. w Nowym Jorku rozpoczęły się nieformalne konsultacje, mające rozwiać ewentualne zastrzeżenia niektórych państw członkowskich ONZ co do nowej wersji projektu. W rezultacie działań UE 18 marca 2011 r. zmodyfikowany projekt rezolucji $\mathrm{w}$ sprawie udziału UE $\mathrm{w}$ pracach ONZ został przekazany do Sekretariatu Generalnego ONZ przez przedstawicieli Węgier ${ }^{40}$.

Jednocześnie UE oraz jej państwa członkowskie podjęły szeroko zakrojoną ofensywę dyplomatyczną, mająca na celu przekonanie do swoich racji tych państw, które głosowały przeciwko pierwotnemu projektowi rezolucji ${ }^{41}$. Działania UE objęły m.in. wysłanie specjalnego listu do wszystkich państw członkowskich ONZ, w którym UE (Wysoka Przedstawiciel) przedstawiała nowy projekt rezolucji, wyjaśniała zmiany do niego wprowadzone i prosiła o wsparcie przy jego uchwalaniu, najlepiej w drodze konsensusu ${ }^{42}$. Wzmożone działania dyplomatyczne skierowano w szczególności do państw CARICOM, do których Przewodniczący Rady Europejskiej wysłał specjalny list; prosił w nim o poparcie przy uchwalaniu projektu rezolucji. W wyniku konsultacji przeprowadzonych 21 kwietnia 2011 r. przedstawiony został kolejny, poprawiony projekt rezolucji, uwzględniający otrzymane zastrzeżenia i uwagi ${ }^{43}$. Znacząca rolę w osiągnięciu ostatecznego sukcesu odegrała postawa Wysokiej Przedstawiciel UE, która przybyła do Nowego Jorku 2 maja 2011 r. Dzięki jej działaniom w przeddzień głosowania $\mathrm{w}$ ZO, w trakcie przyjęcia wydanego $\mathrm{w}$ siedzibie delegatury UE, udało się osiagnąć kompromis z państwami CARICOM, których przedstawiciele w obecności SG ONZ zapewnili o swoim poparciu dla projektu rezolucji ${ }^{44}$. Zmodyfikowany projekt rezolucji został przyjęty przez ZO większością 180 głosów, przy braku głosów przeciwnych i dwóch państwach (Syria, Zimbabwe) wstrzymujących się od głosu ${ }^{45}$.

\footnotetext{
${ }^{39}$ Council of the European Union: Resolution on the effective participation of the European Union in the work of the United Nations General Assembly: Tabling the draft resolution, 7309/11, Brussels, 16 March 2011.

40 A/65/L.64, 21 March 2011.

${ }^{41}$ Council of the European Union: Resolution on the Participation of the European Union in the work of the United Nations: Actions on the draft resolution, 8799/1/11 REV 1, Brussels, 15 April 2011.

42 Ibidem.

${ }^{43}$ A/65/L.64/Rev.1, 21 April 2011.

${ }^{44}$ Council of the European Union: Resolution on the Participation of the European Union in the work of the United Nations: Adoption, 10100/11, Brussels, 12 May 2011.

${ }^{45}$ UNGA Official Records, A/65/PV.88, 3 May 2011.
} 


\section{KATALOG PRAW UNII EUROPEJSKIEJ JAKO OBSERWATORA PRZY ZGROMADZENIU OGÓLNYM ONZ}

Szczegółowy katalog praw UE wynikajacy z rezolucji 65/276 został określony w jej tekście oraz załączniku. Zaznaczyć jednak należy, że na jego zakres mają wpływ również dwa inne dokumenty, a mianowicie: nota SG ONZ dotycząca wprowadzenia w życie warunków udziału przedstawicieli UE w pracach ZO (nota SG) ${ }^{46}$, a także deklaracja interpretacyjna złożona SG ONZ przez Bahamy w imieniu CARICOM (deklaracja CARICOM) ${ }^{47}$.

Preambuła do rezolucji 65/276 podkreśla w pierwszej kolejności rolę i znaczenie $\mathrm{ZO}$ jako jednego z głównych organów ONZ, odpowiedzialnego za realizację celów tej organizacji ${ }^{48}$. Preambuła wskazuje na konieczność prowadzenia współpracy ONZ z organizacjami regionalnymi, uwypukla ponadto fakt, że każda taka organizacja ma całkowitą swobodę w określaniu sposobów jej zewnętrznej reprezentacji. Początkowe motywy preambuły maja zatem za zadanie przypomnienie, że $\mathrm{ZO}$ zachowuje całkowita niezależność i działa w interesie ONZ, a nie na wniosek UE lub jakiejś innej grupy państw. Należy dodać, że z ostatecznej wersji rezolucji $65 / 276$ usunięte zostały wszystkie odniesienia do TL, ponieważ wiele państw członkowskich ONZ uważało, że wewnętrzne zasady funkcjonowania UE (czyli TL) nie moga w żaden sposób być wiążące dla ONZ ani jej państw członkowskich.

Kolejny motyw preambuły odwołuje się do uzgodnień (modalities), jakie każda organizacja regionalna powinna zdefiniować $\mathrm{w}$ związku z ustaleniem zasad jej reprezentacji zewnętrznej. Motyw ten jest pozostałością wcześniejszych wersji rezolucji $65 / 276$ i ma na celu zagwarantowanie tego, że inne organizacje regionalne chcące uzyskać podobny status co UE zachowaja swobodę w określaniu zasad ich współpracy z ONZ i nie będą musiały stosować się do wzorów wypracowanych w ramach UE.

W dalszej części preambuły do rezolucji 65/276 zauważono, że status obserwatora, który został przyznany UE na podstawie rezolucji 3208 (XXIX) w 1974 r. ${ }^{49}$, musi zostać zmodyfikowany w związku ze zmianami powstałymi w rezultacie wzrostu kompetencji przyznanych UE przez jej państwa członkowskie. Motyw ten ma na celu podkreślenie, że pomimo zmian pozycji UE wynikajacych z rezolucji $65 / 276$ wciąż pozostaje ona obserwatorem przy ZO ONZ.

Motyw 6 preambuły przypomina $\mathrm{z}$ kolei o tym, że UE jest sukcesorem Wspólnoty Europejskiej (WE), w związku z czym UE zajęła jej miejsce jako strona wielu umów międzynarodowych przygotowanych pod auspicjami ONZ i uczestnik prac wielu wyspecjalizowanych agencji i organów ONZ. Motyw ten

\footnotetext{
${ }^{46}$ Note by the Secretary General: Participation of the European Union in the work of the United Nations, A/65/856.

${ }^{47}$ Annex to the letter dated 9 May 2011 from the Permanent Representative of the Bahamas to the United Nations addressed to the Secretary-General: Interpretative Declaration by the Bahamas on behalf of the CARICOM, 3 May 2011, in connection with General Assembly resolution 65/276, entitled „Participation of the European Union in the work of the United Nations”, A/65/834.

${ }^{48}$ Szczegółowo na temat preambuły do rezolucji 65/276 zob. P. A. Serrano de Haro, op. cit., s. 24-26.

${ }^{49} \mathrm{~A} / \mathrm{RES} / 3208$ (XXIX).
} 
ma ponadto podkreślić specyfikę UE i odróżnić ją od innych organizacji międzynarodowych mających status obserwatora i tym samym wzmacniać argumenty przemawiające za przyjęciem omawianej rezolucji. Przypomnieć wypada, że problem sukcesji praw i obowiązków po WE został już wcześniej zakomunikowany w liście wysłanym do SG ONZ po wejściu w życie TL list został podpisany wspólnie przez przedstawicieli WE i państwa ówcześnie sprawującego prezydencję $e^{50}$.

W kolejnym motywie zawartym w preambule wymieniono natomiast nowych przedstawicieli reprezentujących UE w stosunkach zewnętrznych (Przewodniczący Rady Europejskiej, Wysoka Przedstawiciel, Komisja Europejska, delegatury UE), co ma zagwarantować jasność w zakresie tego, kto występuje w imieniu UE po wejściu w życie TL.

Część merytoryczna rezolucji 65/276 składa się z 4 paragrafów. Pierwszy z nich potwierdza międzyrządowy charakter ZO ONZ, którego skład ograniczony jest do państw będących członkami ONZ. Celem tego przepisu jest zapewnienie niektórych państw członkowskich o tym, że uchwalenie rezolucji 65/276 nie może być interpretowane jako zmiana charakteru ONZ lub też jako przyznanie UE statusu quasi-członka ONZ ${ }^{51}$.

Paragraf 2 rezolucji 65/276 rozstrzyga o przyjęciu uzgodnień (modalities) zawartych $\mathrm{w}$ jej załączniku, dotyczących udziału przedstawicieli UE (jako obserwatora) ,w sesjach i pracy ZO oraz jego komitetów i grup roboczych, $\mathrm{w}$ międzynarodowych spotkaniach i konferencjach zwołanych pod auspicjami ZO oraz w konferencjach ONZ". W tym kontekście zauważyć należy, że do organów pomocniczych ZO ONZ zalicza się: rady (boards), komisje (commissions), komitety (committees), rady i panele (councils and panels), grupy robocze (working groups) i inne ${ }^{52}$. Omawiana rezolucja dotyczy zatem tylko udziału UE w komitetach ${ }^{53}$ i grupach roboczych ZO ONZ, pomija więc jego pozostałe organy pomocnicze. Wydaje się również, że rezolucja 65/276 nie dotyczy udziału UE w pracach innych głównych organów ONZ, spotkań i konferencji organizowanych pod ich auspicjami, organizacji wyspecjalizowanych, czy też funduszy ONZ (jak np. Światowy Program Żywnościowy) ${ }^{54}$. Wszystkie te organy i organizacje maja bowiem własne regulaminy wewnętrzne, które nie zostały dotąd zmienione pod kątem ,,wzmocnienia” udziału UE w ich pracach. Z drugiej strony rezolucja 65/276 w swoim tytule odwołuje się do ,udziału UE w pracach ONZ”, sugerując tym samym, że dotyczy również

50 P. A. Serrano de Haro, op. cit., s. 25.

51 Ibidem, s. 26.

52 Zgodnie z art. $22 \mathrm{KNZ}$ : ZO może tworzyć „,organy pomocnicze, jakie uzna za stosowne”. Wykaz organów pomocniczych ZO dostępny jest na: http://www.un.org/en/ga/about/subsidiary/index.shtml.

${ }^{53}$ Udział ten dotyczy zarówno komitetów stałych, jak i doraźnych (ad hoc), zob. Participation of Observers in the Ad Hoc Committee to Elaborate International Conventions for the Suppression of Terrorist Bombings and Acts of Nuclear Terrorism - the Right to Attend or Participate as Observers in the Sessions and Work of General Assembly (Note to the Director of the Codification Division, Office of Legal Affairs), „United Nations Juridical Yearbook” 2000, s. 349.

${ }^{54}$ Nota SG wyjaśnia przy tym, że uzgodnienia dotyczące udziału UE w pracach ONZ znajda zastosowanie do międzynarodowych spotkań i konferencji wtedy, gdy żadne dodatkowe prawa i przywileje dotyczące udziału UE nie zostały przyznane przedstawicielom UE w regulaminach wewnętrznych danej konferencji ONZ. 
tych organów i organizacji. W piśmiennictwie podkreśla się w związku z tym, że nie ma wątpliwości, iż prawa zawarte w rezolucji 65/276 nie będą przysługiwały UE w RB ONZ ani w organach, organizacjach, ani funduszach, które uchwaliły już zasady, na jakich UE uczestniczy $\mathrm{w}$ ich pracach ${ }^{55}$. Jeśli jednak chodzi o pozostałe organy, to sprawa udziału UE $\mathrm{w}$ ich pracach będzie musiała zostać wyjaśniona $\mathrm{w}$ praktyce oraz $\mathrm{w}$ drodze interpretacji dokonanej przez Biuro Prawne ONZ ${ }^{56}$.

Zgodnie z paragrafem 3 rezolucji 65/276 ZO ONZ uznaje prawo każdej innej organizacji regionalnej do uzyskania podobnych warunków udziału $\mathrm{w}$ jego pracach, które przyznano UE. Możliwość ta jest jednak uzależniona od spełnienia kilku warunków. Organizacja taka powinna bowiem: wystapić z odpowiednim wnioskiem $\mathrm{w}$ tej sprawie, posiadać już status obserwatora, przyjąć wewnętrzne uzgodnienia umożliwiające jej przedstawicielom występowanie w imieniu organizacji oraz jej państw członkowskich, a ZO powinno uchwalić uzgodnienia określające zasady udziału danej organizacji w jego pracach.

Ostatni paragraf rezolucji 65/276 nakłada na SG ONZ obowiazek poinformowania $\mathrm{ZO}$ o zasadach wprowadzenia $\mathrm{w}$ życie uzgodnień znajdujących się w jej załączniku. Wykonaniem tego obowiązku stała się wspomniana już powyżej nota SG.

W załączniku do omawianej rezolucji zawarto uzgodnienia określające szczegółowe prawa przysługujące UE oraz wymieniono czynności, których UE podejmować nie może. W odniesieniu do praw przedstawiciele UE moga być - po pierwsze - wpisywani na listy mówców przedstawicieli innych dużych grup w celu dokonywania interwencji. Rezolucja 65/276 nie określa precyzyjnie, w jakiej kolejności mają występować przedstawiciele UE. Deklaracja CARICOM podkreśla jednak, że pierwszeństwo państw nad obserwatorami uzasadnia wniosek, że na liście mówców zawierającej wiele grup państw UE nie będzie mogła występować przed żadną z grup, która jest reprezentowana przez pełnego członka ONZ. Natomiast UE może występować przed pojedynczymi państwami członkowskimi.

Po drugie, UE uzyskała możliwość wzięcia udziału w debatach ZO ONZ ${ }^{57}$. Prawo to jest jednak poddane pewnym ograniczeniom wynikającym z porządku procedencji, praktyki dotyczącej obserwatorów oraz poziomu reprezentacji. Zgodnie z notą SG utrwalony porządek wymaga, aby UE zawsze występowała po państwach członkowskich, Stolicy Apostolskiej oraz Palestynie. Praktyka dotycząca obserwatorów wskazuje z kolei na to, że dla ich wystąpień przewidziane są pewne przedziały czasowe, co może być naruszone tylko w wyjątkowych okolicznościach. Nota SG daje przy tym przedstawicielom UE możliwość przedstawienia trzech propozycji terminów takich wystapień (rano lub po południu), w trakcie ogólnych debat sesji zwyczajnych ZO ONZ. W wypadku sesji nadzwyczajnych ZO może zdecydować o innym sposobie

\footnotetext{
${ }_{55}$ J. Wouters, J. Odermatt, T. Ramopoulos, The Status of the European Union at the United Nations after the General Assembly Resolution of 3 May 2011, Global Governance Opinions, July 2011, s. 5.

${ }^{56}$ Ibidem.

${ }^{57}$ Poza państwami członkowskimi ONZ prawo to dotychczas przysługiwało jedynie Stolicy Apostolskiej oraz Palestynie.
} 
ustalania listy mówców. Jeśli natomiast chodzi o poziom reprezentacji UE, to zgodnie z rezolucją 65/276 tworzą ją: Przewodniczący Rady Europejskiej, Wysoki Przedstawiciel Unii ds. Zagranicznych i Polityki Bezpieczeństwa, Komisja Europejska oraz delegatury UE ${ }^{58}$.

Po trzecie, UE ma prawo do przekazywania swoich komunikatów odnoszących się do sesji i prac ZO, a także sesji i prac wszystkich międzynarodowych spotkań i konferencji zwołanych pod auspicjami ZO ONZ. Komunikaty takie moga być dystrybuowane przez właściwy sekretariat bezpośrednio (bez pośrednika), jako dokumenty ZO, spotkania lub konferencji.

Po czwarte, UE ma możliwość ustnego prezentowania propozycji i poprawek uzgodnionych przez państwa członkowskie. W piśmiennictwie wskazuje się, że UE świadomie ograniczyła możliwości przedstawiania swoich stanowisk, warunkując je koniecznościa ,uzgodnienia przez państwa członkowskie”, co wydaje się sprzeczne z treścią i duchem TL ${ }^{59}$. Ponadto propozycje i poprawki UE moga być poddane pod głosowanie tylko na żądanie któregoś z państw członkowskich UE i zgodnie $\mathrm{z}$ odpowiednimi postanowieniami regulaminu wewnętrznego ZO ONZ. Postanowienie to może więc służyć interesom tych państw członkowskich UE, które odmawiają delegaturom UE prawa do reprezentowania ich na forach międzynarodowych ${ }^{60}$.

Po piąte, UE może korzystać z prawa do odpowiedzi dotyczących przedstawianych przez nią stanowisk, jeżeli zdecyduje o tym przewodniczący danego organu. Konieczność uzyskania takiej zgody oznacza w praktyce, że UE nie będzie $\mathrm{w}$ stanie bronić się przed arbitralnymi decyzjami przewodniczącego danego organu. Prawo do odpowiedzi może być realizowane $\mathrm{w}$ kolejności ustalonej przez przewodniczącego i stosowane tylko jeden raz w odniesieniu do każdego punktu porządku obrad.

Po szóste, przedstawiciele UE powinni mieć zapewnione miejsce pomiędzy pozostałymi obserwatorami. Nota SG precyzuje, że miejsce to powinno znajdować się za państwami członkowskimi, państwami nieczłonkowskimi i Palestyna $^{61}$. Znaczące jest to, że przedstawiciele UE moga przy tym zasiadać we wszystkich formalnych posiedzeniach ZO ONZ, jego głównych komitetów oraz organów pomocniczych, a także we wszystkich posiedzeniach nieformalnych, które sa otwarte dla obserwatorów.

Rezolucja 65/276 wskazuje również wyraźnie te prawa, których przedstawiciele UE nie będą mogli wykonywać; zalicza do nich: prawo do udziału w głosowaniach, prawo popierania projektów rezolucji oraz prawo wskazywania kandydatów. Nota SG dodaje, że przedstawiciele UE nie maja prawa do wnoszenia punktów do porządku obrad, których celem byłoby podważenie decyzji przewodniczącego danego organu, ani do składania lub złożenie wniosków proceduralnych w sprawie odroczenia lub zamknięcia debat czy zawieszenia lub odroczenia spotkań.

${ }^{58}$ Zauważyć wypada, że deklaracja CARICOM nie wspomina o ostatnich dwóch podmiotach.

59 J. Wouters, J. Odermatt, T. Ramopoulos, op. cit., s. 3.

60 Ibidem, s. 4.

${ }^{61}$ Należy tutaj uwzględnić późniejsze zmiany pozycji Palestyny, jakie zaszły w związku z nadaniem jej statusu państwa obserwatora. 


\section{WNIOSKI}

W porównaniu z projektem rezolucji, który został odrzucony przez Zgromadzenie Ogólne ONZ we wrześniu 2010 r., ostateczny tekst przyjęty w maju 2011 r. zawiera znacznie mniej uprawnień dla Unii Europejskiej. Przykładowo, w uchwalonej wersji rezolucji nie znalazło się prawo UE do wnoszenia punktów do porządku obrad. Zmiany zauważyć można także w odniesieniu do terminologii dotyczącej korzyści wynikających z integracji na poziomie regionalnym. Wszystkie odwołania do TL, które znalazły się w pierwotnym projekcie rezolucji $65 / 276$, zostały usunięte $\mathrm{z}$ jego ostatecznej wersji ${ }^{62}$. Tym samym $\mathrm{z}$ rezolucji 65/276 znikły wszelkie motywy jej uchwalenia wynikające $\mathrm{z}$,wyjątkowości” integracji państw członkowskich UE w dziedzinie polityki zagranicznej, a sama UE przedstawiona jest jako jedna $\mathrm{z}$ wielu organizacji regionalnych. Zmiany wprowadzone do pierwotnego projektu dają możliwość uzyskania podobnego co UE statusu również innym organizacjom międzynarodowym o charakterze regionalnym ${ }^{63}$. Rezolucja 65/276 stanowi bowiem, że ZO ONZ może przyjąć uzgodnienia dotyczące uczestnictwa $\mathrm{w}$ jego pracach innych organizacji regionalnych, takich jak: Liga Arabska, Unia Afrykańska, CARICOM i ASEAN. Rezolucja 65/276 nie wyjaśnia więc ani przyczyn, ani kontekstu jej uchwalenia. Nie wyjaśnia również, dlaczego UE zdecydowała się podjąć działania zmierzające do wzmocnienia jej udziału w pracach ONZ. W piśmiennictwie wskazuje się $\mathrm{w}$ związku $\mathrm{z}$ tym, że pierwotny projekt rezolucji został całkowicie deeuropeizowany ${ }^{64}$.

Oceniając znaczenie rezolucji 65/276, należy również wskazać na sposób, w jaki UE postrzegana jest przez swoich partnerów. W Europie UE widziana jest jako organizacja międzynarodowa o ponadnarodowym charakterze. Natomiast państwa pozaeuropejskie widzą w UE swoisty „,blok”, którego nie można oddzielić od jego państw członkowskich. Tezy tej dowodzi analiza zapisów debat ZO ONZ, podczas których przedstawiciel Nauru wskazywał, że wzmocnienie statusu obserwatora UE w ZO ONZ będzie się faktycznie równało przyznaniu państwom członkowskim UE dodatkowego 28 głosu podczas debat w ZO, a będzie on służył wyłącznie wzmocnieniu tego, co już wcześniej zostało przez te państwa powiedziane ${ }^{65}$. Ponadto samo $\mathrm{ZO}$ w komunikacie prasowym wydanym po uchwaleniu rezolucji 65/276 opisuje UE jako ,blok państw”66.

Zmiana warunków udziału UE w pracach ONZ w rezultacie uchwalenia przez ZO ONZ rezolucji 65/276 stanowi ważne wydarzenie w rozwoju stosunków pomiędzy tymi dwoma organizacjami międzynarodowymi. Porównanie obecnego statusu UE ze statusem innych państw obserwatorów, np. Stolicy

${ }^{62} \mathrm{~W}$ trakcie debaty w ZO przedstawiciel Wenezueli wskazywał, że projekt rezolucji odnosi się do Traktatu z Lizbony, który nie wiąże zdecydowanej większości państw członkowskich ONZ i nie ma dla nich żadnego znaczenia, zob. UNGA Official Records, A/64/PV.122, 14 September 2010.

${ }^{63}$ Prawo to zostało dodane do projektu rezolucji już we wrześniu 2010 r., w trakcie debaty ZO ONZ, zob. UNGA Official Records, A/64/PV.122. 14, September 2010.

${ }^{64}$ J. Wouters, J. Odermatt, T. Ramopoulos, op. cit., s. 3.

${ }^{65}$ UNGA Official Records, A/65/PV.88, 3 May 2011.

${ }^{66}$ GA/11079/Rev. 1*, 3 May 2011. 
Apostolskiej ${ }^{67}$ lub Palestyny ${ }^{68}$, wykazuje jednak, że zakres praw przysługujących tym podmiotom jest szerszy niż w wypadku UE. Status, jaki UE uzyskała w ZO, nie jest także równoznaczny z statusem tzw. pełnego uczestnika (full participant), który został jej nadany przez RGS w Komisji ds. Zrównoważonego Rozwoju ${ }^{69}$.

Pomimo wskazanych powyżej wad, uchwalenie rezolucji $65 / 276$ jest jednak istotne $\mathrm{z}$ kilku względów ${ }^{70}$. Po pierwsze, rezolucja 65/276 dostosowuje zasady udziału UE w pracach ZO ONZ (i innych organów) do zmian wynikających z Traktatu z Lizbony (zwłaszcza w kontekście reprezentacji UE). Po drugie, rezolucja wzmacnia polityczny status UE w ZO ONZ. Po trzecie, jej uchwalenie jest dla państw pozaeuropejskich sygnałem postępujacej integracji dokonujacej się w ramach UE, z czego państwa te nie zawsze zdaja sobie sprawę (zwłaszcza w odniesieniu do jej tempa i zaawansowania). Po czwarte, rezolucja 65/276 może stać się precedensem dla innych organizacji regionalnych, które również będą chciały „,wzmocnić” swój status obserwatora w ZO ONZ.

dr hab. Marek Zieliński

Uniwersytet Ślaski w Katowicach

marek.zielinski@us.edu.pl

\author{
THE EUROPEAN UNION AS AN OBSERVER \\ AT THE UNITED NATIONS GENERAL ASSEMBLY
}

Summary

The purpose of the present paper is to characterise the UN General Assembly (UNGA) Resolution No. $65 / 276$ on the 'Participation of the European Union in the work of the United Nations.' This resolution was adopted as a result of efforts undertaken by the EU following the entry into force of the Treaty of Lisbon which radically changed the principles and conditions of the EU's participation in other international organisations. Pursuant to the provisions of Resolution 65/276, the EU was granted a new set of new rights at the UNGA as well as in some of its subsidiary bodies, international conferences and meetings held under its auspices. Despite these changes, the status of the EU at the UNGA is not similar to the status of observer states, and Resolution 65/276 points out that the same rights may also be accorded to other regional international organisations. Consequently, the UNGA does not account for the uniqueness of the integration process in the EU member states, treating the EU like any other international organisation.

${ }^{67}$ A/RES/58/314, 16 July 2004. Zob. także: Participation of the Holy See in the work of the United Nations, Note by the Secretary General, A/58/871, 16 August 2004.

68 A/67/L.28, 26 November 2012.

${ }^{69}$ Status ten ponadto pozwala UE wnosić punkty do porządku obrad, a także korzystać z prawa do odpowiedzi w szerszym zakresie, zob. Full Participation of the European Community in the Commission on Sustainable Development, Dec. 1995/201.

${ }^{70}$ G. Grevi, op. cit., s. 5. 
Copyright of Journal of Law, Economics and Sociology is the property of Faculty of Law and Administration of Adam Mickiewicz University in Poznan and its content may not be copied or emailed to multiple sites or posted to a listserv without the copyright holder's express written permission. However, users may print, download, or email articles for individual use.

Właścicielem praw autorskich do „Ruchu Prawniczego, Ekonomicznego i Socjologicznego” jest Wydział Prawa i Administracji Uniwersytetu im. Adama Mickiewicza w Poznaniu. Zawartość czasopisma nie może być kopiowana, przesyłana do innych stron internetowych bądź zamieszczana na blogach bez pisemnej zgody wydawcy. Niemniej artykuły można drukować, kopiować lub przesyłać w formie elektronicznej na własny użytek. 